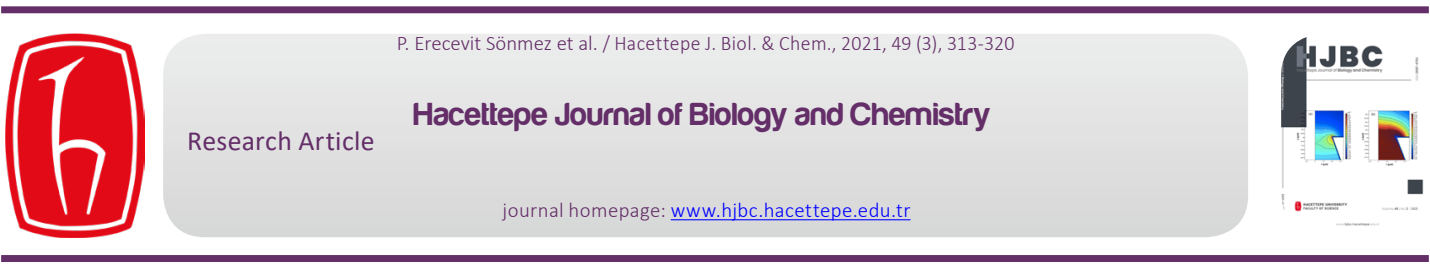

\title{
Inhibitory Property of Poly (AN-co-VP) Copolymer on Some Dermatophyte Fungi and Yeasts Causing Fungal Infections
}

\section{Mantar Enfeksiyonlarına Neden Olan Bazı Dermatofit Funguslar ve Mayalar Üzerinde Poli (AN-co-VP) Kopolimerin İnhibitör Özelliği}

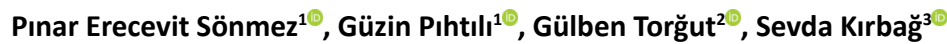 \\ ${ }^{1}$ Department of Medical Services and Techniques, Pertek Sakine Genc Vocational School, Munzur University, Tunceli, Turkey. \\ ${ }^{2}$ Department of Chemistry and Chemical Processes, Tunceli Vocational School, Munzur University, Tunceli, Turkey. \\ ${ }^{3}$ Department of Biology, Firat University, Faculty of Science, Elazığ, Turkey.
}

\section{ABSTRACT}

\begin{abstract}
ntimicrobial susceptibility test for poly (AN-co-VP) copolymer, which we think could be an ideal drug in treatment interventions was evaluated with disk diffusion method and minimum inhibitor concentration. In the antimicrobial measurement data, it was determined that the poly (AN-co-VP) copolymer dissolved in pure water is a significant inhibitory property against the growth of yeast (on Candida spp. with $11.33 \pm 0.3 \mathrm{~mm}$ barrier area) and dermatophyte fungi (on Epidermophyton sp. and Trichophyton sp. with $12.33 \pm 0.3$ $\mathrm{mm}$ barrier area) $(\mathrm{p}<0.001)$ and no inhibitory properties were observed in preventing the growth of all bacteria (Escherichia coli, Pseudomonas aeruginosa, Klebsiella pneumoniae, Staphylococcus aureus, Bacillus megaterium). MIC limit values that prevent the growth of dermatophytes and yeasts supporting the disc diffusion method are 50-100 $\mu \mathrm{L}$. This study is an alternative approach in order to limit the spread of superficial fungal infections they cause and eliminate these infections that tend to become chronic since this polymer extract has no inhibitory properties on bacteria but prevents the growth of yeast and dermatophytes.
\end{abstract}

Key Words

Copolymer, antifungal, alternative therapeutic drug, inhibitory property.

\section{öz}

\begin{abstract}
Tedavi girişimlerinde ideal bir ilaç olabileceğini düşündüğümüz poli (AN-co-VP) kopolimer için antimikrobiyal duyarlılık testi disk difüzyon yöntemi ve minimum inhibitör konsantrasyonu ile değerlendirildi. Antimikrobiyal ölçüm verilerinde saf suda çözünmüş poly

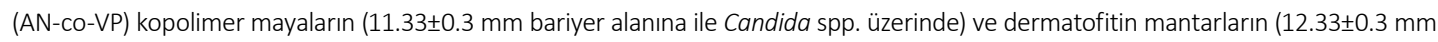
bariyer alanı ile Epidermophyton sp. ve Trichophyton sp. üzerinde) $(p<0.001)$ büyümesine karşı önemli bir engelleyici özellik gösterdiği belirlenmiştir ve tüm bakterilerin (Escherichia coli, Pseudomonas aeruginosa, Klebsiella pneumoniae, Staphylococcus aureus, Bacillus megaterium) büyümesini engellemede herhangi bir inhibitör özellik gözlenmemiştir. Disk difüzyon yöntemini destekleyen dermatofit ve mayaların büyümesini engelleyen MiK sınır değerleri 50-100 $\mu$ L`dir. Polimer ekstraktının bakteriler üzerinde engelleyici özelliği yoktur, ancak maya ve dermatofitlerin büyümesini engellemiştir. Bu çalışma, neden oldukları yüzeysel mantar enfeksiyonlarının yayılmasını sınılamak ve kronik olma eğiliminde olan bu enfeksiyonları ortadan kaldırmak için alternatif terapotik bir ilaç etken maddesi girişimi için yapılmıştır. Bu yüzden elde edilen antimikrobiyal duyarlılık testi verilerine göre bu polimer tedavi amaçlı olarak yeni fungal ilaçların formulasyonlarında kullanılabilir.
\end{abstract}

\section{Anahtar Kelimeler}

Kopolimer, antifungal, alternatif terapotik ilaç, inhibitör özellik.

Article History: Received: Sep 20, 2020; Revised: Dec 8, 2020; Accepted: Jan 7, 2021; Available Online: May 7, 2021. DOI: https://doi.org/10.15671/hjbc.800069

Correspondence to: P.E. Sönmez, Depart. Medic. Servic. and Techn., Pertek Sakine Genc Vocational School, Munzur University, Tunceli, Turkey E-Mail: pinarerecevit@hotmail.com 


\section{INTRODUCTION}

ome medicines nowadays used to eliminate fungal infections are not many compared to those used for bacterial infections. The development of resistance against this limited number of drug groups require defective measures to be taken, especially at the end of the 90's. Antifungal sensitivity tests, which are the first step in the regulation of the treatment of fungal infections, thanks to studies conducted in our country and then the selection of the appropriate antifungal was made [1]. Only 50 of 12 million fungal species found in litarature cause diseases in humans and animals [2] Candida species are the most common types of superficial and deep fungal infections. However, molds and dermatophytes are among the most common species [3].

Many examples are known to show that Candida is opportunistic pathogens. Yeast fungi belonging to the genus Candida is found in humans in the normal flora of the skin and gastrointestinal tract, genitourinary tract and respiratory tract mucosa, and can also be found in soil and food [4]. The most common clinical symptom caused by Candida species is candidemia. Candidemia is a serious clinical condition with high mortality and difficult to diagnose and treat. Another clinical picture caused by Candida species is urinary system fungal infections [5].

However, an increase of more than $50 \%$ was observed in the incidence of non-albicans Candida spp. such as the cause of Candidiasis, C. glabrata, C. parapsilosis, C. tropicalis, C. krusei, C. lusitaniae, C. dubliniensis and C. guilliermondii. Due to the resistance of Candida to different treatments and the emergence of some toxic effects due to antifungal treatments, studies have been carried out to develop alternative drugs in recent years [6]. Dermatophytes, one of the most common agents of superficial fungal infections, are also common in our country. Dermatophytes are examined under three genera as "Trichophyton, Epidermophyton, and Microsporum". When looking at the tissues where it is located, Microsporum type hair and skin, Epidermophyton type skin and nails, Trichophyton species hair, skin and nails [7].

Dermatophyte infections, although very contagious and widespread, were previously underestimated as they are generally not life- threatening. However, the importance of fungal infections, including dermatophytes has increased gradually due to reasons such as, the number of patients with vaccinated efficacy and the increase in the elderly population, the use of drugs with inhibitory properties in many pathogens [8]

Polymers have used as potential alternative candidates for preservatives in food packaging to provide a variety of natural therapeutic agents in the treatment of diseases and other applications [9-11].

In recent years, the preparation of organic-inorganic copolymer has become the focus of attention due to low cost in production and high mechanical strength. The interesting studies are present on the synthesis of the AN and VP copolymer, which is a component of this polymer. These alternative medicines can consist of herbal or polymer compounds. There is no study on the biological properties of this copolymer. Only very few studies of the groups within it have been done for therapeutic and antibacterial purposes [12-18].

As a result of our extensive research on the healing of fungal infections caused by Candida and dermatophyte strains and resistance to antifungals, this polymer; No data was found on poly (AN-co-VP) copolymer. This study will reflect the preliminary data. This study was conducted as an alternative approach in terms of eliminating fungal infections that are difficult to treat. The goal of this study was to provide therapeutic drugs to be used in formula as the drug substance in pharmaceutical industry to remove severe fungal infections that are highly fatal, difficult to treat in humans.

\section{MATERIALS and METHODS}

\section{Screening of inhibitory property}

\section{The sample collection and preparation}

This polymer synthesized by Tanyol et al. was made suitable for grinding [19]. The grinded polymer (0.45 g) was treated in $5 \mathrm{~mL}$ pure water solvent by keeping on a rotary shaker (100 rpm) for $24 \mathrm{~h}$. Thus, the polymer extract was obtained. These polymer materials were filtered under suitable aseptic conditions and left at $4^{\circ} \mathrm{C}$ for further study. Then, $100 \mu \mathrm{L}\left(9 \mathrm{mg} \mathrm{L}^{-1}\right)$ of polymer extracts were injected into $6 \mathrm{~mm}$ diameter (Schleicher\& S hüll No: 2668, Germany) blank antibiotic paper discs to try the test isolates separately. 


\section{Microbial strain}

The bacteria (Escherichia coli ATCC 25922, Pseudomonas aeruginosa DSM 50071, Klebsiella pneumoniae FMC 5, Staphylococcus aureus COWAN 1, Bacillus megaterium DSM 32), yeasts (Candida albicans FMC 17, Candida glabrata ATCC 66032) and dermatophyte (Trichophyton $s p$., Epidermophyton sp.) were tested as species for the current study. The tested pathogens were taken by the Department of Biology, Firat University, Microbiology Laboratory, Elazig-Turkey.

\section{Inhibitory property tests}

\section{Agar disc diffusion method}

The agar disc diffusion method was performed in order to detect inhibitory effect. Mueller Hinton Agar, Yeast Malt Extract Agar and Sabouraud Dextrose Agar were prepared separately in erlen-meyer bottles under laboratory conditions and brought to $45-50^{\circ} \mathrm{C}$ pouring temperature, with the culture of microorganisms to be prepared as explained, will be added at the incidence of $\% 1\left(10^{6}\right.$ cells $\mathrm{mL}^{-1}$ of bacteria, $10^{4}$ cells $\mathrm{mL}^{-1}$ yeast and dermatophyta fungi as per $\mathrm{Mc}$ Farland standard). $15 \mathrm{~mL}$ medium by shaking well is pou red in to sterile petri plates and homogenously distributed. The discs ( $6 \mathrm{~mm}$ diameter) with treated $100 \mu \mathrm{L}$ of polymer extract were added to the appropriate agar media inoculated with microorganism. Then, petri dishes was stored at $4^{\circ} \mathrm{C}$ for $2 \mathrm{~h}$. The cultivated petri dishes were left in the incubator at $37 \pm 0.1^{\circ} \mathrm{C}$ at $24 \mathrm{~h}$ for bacterial isolates and also at $25 \pm 0.1^{\circ} \mathrm{C}$ at $72 \mathrm{~h}$ for yeasts and dermatophyte. The antibacterial, antifungal, antidermatophyta characteristic of polymer extract was evaluated by observing the inhibition area on the disks [18]. Micostatin and ampicillin sulbactam were used as positive control. No negative control was used as the samples were dissolved in pure water. The experiment was repeated twice.

\section{Minimal inhibition concentration}

Minimal inhibitory concentrations (MIC) were detected using the Broth dilution assay. The cultures were obtained in MuellerHintonBroth (Difco, Difco Laboratories, Detroit, MI, USA). The passages of microorganisms were prepared with 12- hour broth cultures and the passages were set at a blur of $0.5 \mathrm{Mc}$ Farland Standard. The polymer was first rare filed to the maximum value $100 \mu \mathrm{L}$ to be evaluated, and then serial 2-fold subtilizations were acquired in a values serial from 6.25 to $100 \mu \mathrm{L}(562.5$ $-9000 \mu \mathrm{g})$ in $10 \mathrm{~mL}$ aseptic test tubes including nutrient broth for bacteria and sabouraud dextrose broth for yeast and dermatophyta fungi. MIC values of this polymer against analyzed microorganisms were revealed with a micro-well dilution method [20]. The propagation of microorganisms was determined by an EL x 800 universal microtiter plate reader at $600 \mathrm{~nm}$ with optical density quantity. After incubation for $18-24 \mathrm{~h}$ at $37 \pm 1^{\circ} \mathrm{C}$ for bacteria, $25 \pm 0.1^{\circ} \mathrm{C}$ at $72 \mathrm{~h}$ for yeast and dermatophyte pathogens. It was defined as the smallest value of that sample for the nominal value of the polymer used toprevent proliferation of microorganisms. This is the last tube symbolization ( $\mathrm{mg} \mathrm{mL}^{-1}$ ) whose demectric is not microbial growth.

\section{Statistical analysis}

Statistical comparisons were made between the extract and control groups (ampicillin sulbactam, micostatin) in relation to measurable preventive activity against bacteria, yeast and dermatophytes. SPSS soft ware was used for statistical evaluation (SPSS Inc., Chicago IL). The values were achieved by analysis of variance (ANOVA) and the lowest significant difference (LSD) tests were specified as mean $\pm \mathrm{SE}$. $\mathrm{P}<0.001$ were evaluated for the variations between extract and control groups. $P$ value given as foot notes below Table 1 and 2 were considered significant effect. This study was conducted in three repetition.

\section{RESULTS and DISCUSSION}

\section{Inhibitory property}

There occurs many interactions when polymeric biomaterials come into contact with living tissue or physiological fluids. Biomaterials have wide application areas in medicine and dentistry because of the tissue interactions, bioactivity, and antimicrobial properties that they constitute in their environment. Their resistance decreases against a hypotonic environment. Molecules that emerge as a result of burning the substances taken into the body transforming into energy by burning them with oxygen can secrete toxic products such as oxidants. For example, pharmaceutical products and the development of implant materials occur through cell-substrate interaction. It is enough to research the substrates to which cells attach and develop in living systems to obtain information on the effect of substrates on the cells. The drug may have side effects on other tissues during the transport of the drug to tumors or diseased tissues. Controlled drug release systems (delivery of the active substance to the target in the body) have been developed to remove or minimize these side effects. Moreover, biocompatible polymers can be biodegraded when 
they are utilized in drug delivery systems. Non-toxic alcohols during degradation and other low molecular weight products formed when decomposing can be easily eliminated by creating acids [21].

While the antimicrobial measurement data showed that this extract constitutes an important barrier area in yeast and dermatophyte fungi against the development of the microorganisms tested, it was determined that no barrier area was observed in preventing the growth of all bacteria showed (Table 1-2).

The obtained disk diffusion evaluation results were supported by the results of minimal inhibition concentration, and this polymer extract was proven to have antifungal and antidermatophyte properties.

Polymer extract has significant barrier area with $11.33 \pm 0.57 \mathrm{~mm}$ on C. albicans, C. glabrata from yeast $(\mathrm{P}<0.001 ; \mathrm{d})$ and with $12.33 \pm 0.33$ against Epidermophyton $s p$. and Trichophyton sp. from dermatophyta fungi. These data are used as antimicrobial polymer for healing efforts on yeast infections dermatophytes and Candida spp. It is an indication that it can be used (Table 1).

Additionally, when looking at the inhibitory property of the polymer extract, compared to the standard antibiotic, this extract has shown a noticeable feature in preventing proliferation of yeast and dermatophyte fungi.

To strengthen the antibiotic test; The antimicrobial properties of this polymer extract have been tested in bacteria, yeast and dermatophyte fungi with MIC values at concentrations ranging from $100 \mu \mathrm{L}$ to $6.25 \mu \mathrm{L}$.
The data are given in Table 2; The result of the evaluation of the growth of all pathogenic microorganisms for this extract by MIC analysis was obtained.

The MIC values of the polymer against the growth of dermatophyte fungi and yeast ranged from $50 \mu \mathrm{L}$ to $100 \mu \mathrm{L}$ on average. According to this; results C. albicans, Epidermophyton $s p$. growth inhibitory concentration is $50 \mu \mathrm{L}$, C. glabrata, Trichopyton sp. for $100 \mu \mathrm{L}$. On the other hand, it did not inhibit the growth of bacteria ( $E$. coli, S. aureus, B. megaterium, $P$. aeruginosa) in any of the concentration range of 100 to $6.25 \mu \mathrm{L}$. In this case; the extract showed a good inhibitory property for $C$. albicans, Epidermophyton sp. and C. glabrata, Trichopyton sp. with the lowest concentration of 50 and $100 \mu \mathrm{L}$ (Table 2).

In previous studies, it was stated that antifungal susceptibility tests should be performed first and then the appropriate antifungal should be selected to eliminate fungal infections [1].

The feature that distinguishes this study is that this polymer was first tested on these microorganisms and contributed to the pharmaceutical industry with its effectiveness on dermatophyte fungi and yeasts that cause chronic diseases in humans.

Table 1. The inhibitory property of poly (acrylonitrile-co-N-vinylpyrrolidone) copolymer by the agar disc diffusion method.

\begin{tabular}{ccc}
\hline Microorganisms & $\begin{array}{c}\text { Poly (acrylonitrile-co- } N \text {-vinylpyrrolidone) } \\
\text { coploymer extracts }\end{array}$ & $\begin{array}{c}\text { Negative Control } \\
\text { Standart antibiotics }\end{array}$ \\
\hline E. coli & - & $12.33 \pm 0.3^{*}$ \\
\hline S. aureus & - & $10.33 \pm 0.3^{*}$ \\
\hline B. megaterium & - & $12.33 \pm 0.3^{*}$ \\
\hline P. aeruginosa & - & $12.33 \pm 0.3^{*}$ \\
\hline K. pneumoniae & - & $19.66 \pm 0.3^{*}$ \\
\hline C. albicans & $11.33 \pm 0.3^{\mathrm{d}}$ & $12.33 \pm 0.33^{* *}$ \\
\hline C. glabrata & $11.33 \pm 0.3^{\mathrm{d}}$ & $8.66 \pm \pm 0.33^{* *}$ \\
\hline Epidermophyton sp. & $12.33 \pm 0.3^{\mathrm{d}}$ & $8.66 \pm 0.33^{* *}$ \\
\hline Trichophyton sp. & $12.33 \pm 0.3^{\mathrm{d}}$ & $8.66 \pm 0.33^{* *}$
\end{tabular}

The positive control; ampicillin sulbactam $\left(^{*}\right)$ and mikostatin $(* *)(100 \mu \mathrm{L}$ and $20 \mu \mathrm{g} / \mathrm{disc})$. No negative control was used as the samples were dissolved in pure water. Inhibition zone $>15 \mathrm{~mm}$ (highly significant effect; $p<0.0001 ; c d$ ), $15-10 \mathrm{~mm}$ (significant effect; $p<0.001 ; \mathrm{d}$ ) : it has not inhibitory property 
Table 2. The antimicrobial characteristic of poly (acrylonitrile-co- $\mathrm{N}$-vinyl pyrrolidone) copolymer by the minimum inhibition concentration (MIC in $100 \mu \mathrm{L}$ ).

\begin{tabular}{cc}
\hline Microorganisms & $\begin{array}{c}\text { Inhibition area }(\mu \mathrm{L}) \\
\text { Poly (acrylonitrile-co-N-vinylpyrrolidone) coploymer extracts } \\
\text { MIC values }\end{array}$ \\
\hline E. coli & - \\
\hline S. aureus & - \\
\hline B. megaterium & - \\
\hline P. aeruginosa & 50 \\
\hline C. albicans & 100 \\
\hline C. glabrata & 50 \\
\hline Epidermophyton sp. & 100 \\
\hline Trichophyton sp.
\end{tabular}

In a study conducted on Candida species, it was reported that formic acid, a low-cost substance, can be used in treatment at low doses, although it is toxic in high doses. This makes us think that antimicrobial agents to be used should be at low doses [4]. Again, In a study for inhibitory property showed that poly (vinyl pyrrolidone) was identified as microbicidal [12]. Our data accord to being this polymer fungicidal by using a low dose.

Factors that affect antimicrobial activity of polymers are molecular weight, deacetylation degree, $\mathrm{pH}$ and temperature. Both the effect of these factors and the increase in the rate of the amine group in the polymer structure used in the study interacting with the culture medium of the microorganisms and reacting with the negatively charged microorganism cell wall explain the antimicrobial effect mechanism of polymer on microorganisms [22].

Many copolymers that gain importance with their reactive functional groups are synthesized, tested and used for the properties of functional groups. Polymers that can destroy pathogenic microorganisms are also called polymeric biocides with antimicrobial properties.

Studies on the properties of both compounds (acrylonitrile and vinylpyrrolidone) are few in number. No studies have been conducted on dermatophyte and Candida species.

In one study, N-vinylpyrrolidone- maleic anhydride copolymer and copolymer complexes prepared with copolymer, N, N-diethylaminoethanol (1: 1, 1; 2) showed high inhibitory properties on all four gram negative bacterial strains [13]. There have been no trials on dermatophytes and fungi. The copolymer we used in our study did not show any inhibitory properties on 2 gram positive and 2 gram negative bacteria. We think that the reason for this is that the compounds contained in the copolymer are different and their amounts are not the same.

$\mathrm{N}$-vinylpyrrolidone, due to its water-soluble structures and low cytotoxicity. Since it is known that it does not cause a harsh immune response to the substance, applications in different fields have been evaluated widely. Homo and copolymers of $\mathrm{N}$-vinylpyrrolidone are scientifically interesting due to their different properties and allow their use.

Bio-tolerant polymers and low toxicity bio-useful compounds, coagulants and flocculants 2-hydroxymethyImethacrylate and $\mathrm{N}$-vinylpyrrolidone copolymer are used in drug interventions such as cancer therapy.

In the study on the antibacterial property of Poly (N-vinylpyrrolidone-co-acrylic Acid)/Diethylaminoethanol, it showed an important inhibitory effect on all bacteria with a concentration of $1500 \mu \mathrm{g}$ per well. On all bacteria, the ester of the copolymer shows more properties as it contains the amine group, which is more antibacterial than the carboxylic acid group [14]. In our study, the reason why poly (acrylonitrile-co-N-vinyl-2pyrrolidone) copolymer does not show inhibitory properties on bacteria is the low concentration of the copolymer and its antagonistic effect on the properties of the compounds (acrylonitrile, N-vinyl-2-pyrrolidone), which contain reactive functional groups. 
Studies have revealed that using Curcuma longa increases antibacterial properties in polyacrylonitrile (PAN). PAN / C. longa prevented the proliferation of gram positive bacteria more than gram negative bacteria. The most suitable biocide should not generate toxic products or cause any adverse reactions that could be evaluated by in vitro cytotoxicity tests. In addition, due to the non-cytotoxicity of the polymer, an excellent cell viability was observed in the PAN matrix with $200 \mathrm{mg} \mathrm{ml}^{-1}$ curcumin loading [15].

The most suitable polymer to be used for wound dressing should be easy to remove, such as non-cytotoxic, biodegradable, impermeable to bacteria. It has been stated that poly acrylonitrile is used as a wound dressing material in a single application to facilitate the healing process [17]. In our study, the reason why the copolymer containing acrylonitrile does not show inhibitory properties on bacteria is the negative interaction with other functional compounds and its large molecular weight.

It was found that both compounds were nontoxic in other studies. The expression proves that this co polymer used in our study is the ideal antimicrobial polymer. The fact that polyacrylonitrile nanofibers have the least antibacterial activity on E. coli and S. aureus used in our study supports the fact that the copolymer used in our study does not show properties on bacteria [17]. Namely, it is in line with the data of our study.

In a study, Poly (vinyl- pyrrolidone) nanofibers to evaluate the inhibitory effects of the structure of the metal on some bacteria (E. coli and S. aureus), with different metallic nanofibers ( $\mathrm{Ag}$, Cu and $\mathrm{Zn}$ ) was prepared. It is explained that the reason for its effect on bacteria is due to the antimicrobial activity mechanisms of the polymer, as well as the toxic effect of low molecular weight substances through the cell membrane more quickly. Moreover, according to another explanation, a different speciation has been made in the cultural environment. It is accepted that metals combine with thiol protein groups leading to membrane damage and intracellular metabolic degradation. Silver nanoparticles have been reported to produce reactive oxygen species (ROS) that damage bacterial DNA or mitochondria [16]. The data obtained explain the reason why the polymer is fungicidal that it damages cell membranes by entering a different interaction in the culture medium where fungi are present and the formation of cationic antimicrobial compounds that affect cell mechanisms.
In a study involving acrylonitrile, acrylic acid and acrylonitrile were added to cellulose fluff pulp using ceric ammonium nitrate as the initiator. It has been determined that it gives high antimicrobial activity [23].

It has been reported that polyvinylpyrrolidone-based hybrid materials containing silver nanoparticles demonstrate a high level of microbicidal effect against the growth of bacteria and fungi species used. Accordingly, Antimicrobial activity has been observed against S. aureus; gram-positive bacteria, E. coli; gram-negative bacteria, $P$. aeruginosa; non-fermented gram-negative bacteria and different yeasts and molds such as Candida krusei, Candida tropicalis, Aspergillus brasiliensis. In addition, there is no antimicrobial effect against Bacillus subtilis spores, C. albicans and C. glabrata [24]. It is thought that the reason for showing in C. albicans and $C$. glabrata depends on the dosage used. It is compatible with showing microbicidal properties on fungi when we compared with the data obtained.

There is a need for new antifungalswhose in vitro efficacy is determined in order to prevent fungal infections from be coming both chronicity and easy to spread and because of the emergence of resistant fungal pathogens.

An ideal drug should have a wide spectrum of efficacy in low concentrations, fungicidal, fungicide and should not develop fungal resistance, even side effects [25]. Because this polymer is antifungal against the growth of yeast and dermatophytes, it has the potential to be used among the ideal drugs to treat dermatophytosis and candidemia. Inaddition, the data obtained proved that this polymer, which is a low-cost substance, is not toxic at high doses, but can also be used for therapeutic purposes at low dose.

In contrast to the cholesterol structure found in mammalian cell membranes, fungi have an ergosterol structure in their cell membranes in contrast to the cholesterol structure found in mammalian cell membranes besides the general antimicrobial mechanism with negatively charged cell membrane interaction of ( $\mathrm{N}-$ ) cationic groups in the structure of the copolymer. The structures in the polymer showed that squalenei that is the first stage of the biological synthesis of ergosterol, may avoid the epoxidation step of ergosterol and thus cause squalene accumulation. The death of the fungal 
cell by this mechanism is not due to ergosterol deficiency but by the accumulation of squalene in the cell membrane $[19,26,27]$. It is observed that the polymer in study is effective on strains of Candida.

According to results of antimicrobial susceptibility, copolymer can be utilized as an alternative therapeutic drug active ingredient for limiting the spread of superficial fungal infections and eliminating these infections that tend to be chronic. We also think that this polymer can contribute to different application areas in health due to research and development studies.

\section{Acknowledgments}

The authors state that did not have conflict of interests.

\section{References}

1. A. Kalkancı, A. Biri, G. Bozdayı, S. Kuştimur, Sensitivity of Candida spp samples to some antifungals obtained from vulvovaginal candidiasis cases, Türkiye Klinikleri J. Gynecol Obst., 15 (2005) 87-90.

2. H. Uslu, A.E. Aktaş, A. Ayyıldız, M. Melikoğlu, Dermatophytic foot agents in patients with different clinical diagnosis, AÜTD, 36 (2004) 83-87.

3. F. Yıldız, Z. Aşçı Toraman, Typing of dermatophytes and yeasts detected as superficial fungal infectious agents in diabetic patients, determination of antifungal susceptibility of yeasts, F.Ü.Sağ.Bil. Tıp., 34 (2020) 41-47.

4. S. Seyedmousavi, M. İlkit, M. Durdu, C.. Ergin, S. HilmioğluPolat, W. Melchers, P. Vervei, Candida and candidiasis: epidemiology, diagnosis, treatment, antifungal drug resistance, and current status of host genetic susceptibility, J. Türk Mikrobiyol. Cem. Derg., 45 (2015) 1-11.

5. L. Andres, M. Carpio, A. Climaco, Fungemia candidiasis. Statperals Publishing LLC. Treasure Island (FL), 2020. Jan. Available from: https://www.ncbi.nlm.nih.gov/books/ NBK436012/

6. H. Sav, G. Demir, M.A. Atalay, A.N. Koç, Evaluation of Candida species isolated from clinical samples, Türk Hij. Den. Biyol. Derg., 70 (2013) 175-80.

7. E. Eryılmaz, R. Samadzade, S. Maçin, D. Fındık, Dermatophytes detected in patients who applied to Konya Selçuk University Hospital, J. Fungus., 10 (2019) 84-88.

8. R. Altinbaş, Yüzeysel mantar enfeksiyonları etkenlerinden dermatofitler ve immunopatogenez, Mersin Akademi Yayınları, ISBN: 978-605-69921-7-9- Mer Ak Publishing House, Health Soc. Sci., p.10-25

9. M. Ignatova, N. Manolova, I. Rashkov, Electrospinning of poly (vinyl pyrrolidone) -iodine complex and poly (ethylene oxide) /poly (vinyl pyrrolidone)-iodine complex-a prospective route to antimicrobial wound dressing materials, Eur. Polym. J., 43 (2007) 1609-1623.

10. M. Liana-Ruiz-Cabello, S. Pichardo, J.M. Bermudez, A. Banos, C. Nunez, E. Guillamon, S. Aucejo, A.M. Camean, Development of PLA films containing oregano essentialoil (Origanum vulgare L. virens) intended foruse in food packaging, Food Addit Contam.: Part A., 33 (2016) 1374 1386.
11. A. Fraj, F. Jaâfar, M. Marti, L. Coderch, N. Ladhari, A comparativestudy of oregano (Origanum vulgare L.) essential oil-based poly caprolactone nano capsules / microspheres: preparation, physicochemical characterization, and storage stability, Ind. Crops Prod., 140 (2019) 111-669.

12. J. Jiang, L. Zhu, L. Zhu, H. Zhang, B. Zhu, Y. Xu, Antifouling and antimicrobial polymer membranes based on bioinspired polydopamine and strong hydrogen-bonded poly ( $\mathrm{N}$-vinyl pyrrolidone), ACS Appl. Mater. Interfaces., 5 (2013) 1289512904.

13. P. Hemalatha, M.K. Veeraiah, S. Prasannakumar, K.V. Anasuya, Synthesis characterisation and antibacterial activity of copolymer ( $\mathrm{N}$-vinylpyrrolidone- maleic anhydride) with $\mathrm{N}$ diethylethanolamine, IJRET., 3 (2014) 56-64.

14. P. Hemalatha, M. K. Veeraiah, S. Prasanna Kumar, K.V. Anasuya, M. Manju, R. Naika Lingaraju, Antibacterial properties of poly ( $\mathrm{N}$-vinylpyrrolidone-co-acrylic acid)/ diethylaminoethanol ester, Indian J. Adv. Chem. Sci., 2 (2014) 50-54.

15. P. Govindaraj, B. Kandasubramanian, K.M. Kodam, Molecular interactions and antimicrobial activity of curcumin (Curcuma longa) loaded polyacrylonitrile films, Mater. Chem. Phys., 147 (2014) 934-941.

16. J. Quiros, J.P. Borges, K. Boltes, I. Rodea-Palomares, R. Rosal, Antimicrobial electrospun silver- copper- and zinc-doped polyvinylpyrrolidone nanofibers, J. Hazard. Mater., 299 (2015) 298-305.

17. O.E. Fayemi, A.C. Ekennia, L. Katata-Seru, A.P. Ebokaiwe, O.M. Ijomone, D.C. Onwudiwe, E.E. Ebenso, Antimicrobial and wound healing properties of polyacrylonitrile- moringa extract nanofibers, ACS Omega., 3 (2018) 4791-4797.

18. G. Torğut, G. Pıhtılı, P. Erecevit Sönmez, Y. Erden, S. Kırbağ, Synthesis, and antimicrobial and anticancer activities of sodium acrylate copolymers, J. Bioact. Compat. Poly., 35 (2020) 179-188.

19. M. Tanyol, N. Kavak, G.Torgut, Synthesis of Poly (AN-coVP) /zeolite composite and Its application for the removal of brilliant gren by adsorption process: kinetics, isotherms, and experimental design, Hindawi Adv. Polym.Tech., (2019) p.12.

20. NCCLS. Methods for dilution and antimicrobial susceptibility tests for bacteria that grow aerobically; approved standardfifth edition, NCCLS document M7-A5, NCCLS, Wayne, P A, USA, 2000.

21. Z. Tüylek, Smart polymers used in the field of health, JHVS, 7 (2019) 81-95.

22. P. Arslan, A. E. Tayyar, Antimicrobial materials, working mechanisms, applications and antimicrobial efficiency assessment methods in textile field, DUBITED, 4 (2016) 935 966.

23. W. Dahou, D. Ghemati, A. Oudia, D. Aliouchea, Preparation and biological characterization of cellulose graft copolymers, Biochem Eng. J., 48 (2010) 187-194.

24. R. Bryaskova, D. Pencheva, S. Nikolov, T. Kantardjiev, Synthesis and comparative study on the antimicrobial activity of hybrid materials based on silver nanoparticles (AgNps) stabilized by polyvinylpyrrolidone (PVP), J. Chem Biol., 4 (2011) https://doi.org/10.1007/s12154-011-0063-9

25. A. Özkütük, Typing of dermatophytes isolated from dermatomycosis cases and their sensitivity to antifungal agents, Master Thesis, İzmir, Dokuz Eylul University, Faculty of Medicine, Department of Microbiology, p. 48, 1999. 
320 P. Erecevit Sönmez et al. / Hacettepe J. Biol. \& Chem., 2021, 49 (3), 313-320

26. U. Yıldız, Synthesis and characterization of poly (allyl guanidine. $\mathrm{HCL}$ ) and investigation of its antimicrobial property, Master Thesis, Master Hacettepe University, Department of Chemistry. p.74, 2013.
27. Z. Yıldırım, N. Öncül, M. Yıldırım, Chitosan and antimicrobial properties, NGU J. Eng. Sci., 5 (2016) 19-36. 